\title{
Towards a calcium-based rechargeable battery
}

3

(1)

${ }^{2}$ Toyota Motor Europe, Research \& Development 3, Advanced Technology 1,Technical Centre,

${ }^{1}$ Institut de Ciència de Materials de Barcelona (ICMAB-CSIC) Campus UAB, E-08193 Bellaterra, Catalonia (Spain) Hoge Wei 33 B, B-1930 Zaventem, (Belgium).

Corresponding author: M. R. Palacín (e-mail: rosa.palacin@icmab.es)

(1)

The development of a rechargeable battery technology using light electropositive metal anodes would bring in a breakthrough in energy density. ${ }^{1}$ For multivalent charge carriers $\left(M^{n+}\right)$, the number of ions that must react to achieve a certain electrochemical capacity is diminished by two $(\mathrm{n}=2)$ or three $(\mathrm{n}=3)$ when compared to $\mathrm{Li}^{+}{ }^{2}$ While proof-ofconcept has been achieved for magnesium, ${ }^{3,4,5}$ the electrodeposition of calcium was thought to be impossible to date ${ }^{6}$ and research restricted to non rechargeable systems. ${ }^{7,8,9,10}$ Here we demonstrate the feasibility of calcium plating at moderate temperatures using conventional organic electrolytes, such as those used for the Li-ion technology. The reversibility of the process upon cycling has been ascertained and thus the results presented here constitute the first step towards the development of a new rechargeable battery technology using calcium anodes. 
Amongst multivalent electropositive metals, an aluminium based cell ${ }^{11}$ has been recently reported which, in spite of limited potential $(2 \mathrm{~V})$ and capacity $(70 \mathrm{mAh} / \mathrm{g})$ values, does exhibit fast rate capability. Calcium is an especially attractive alternative as it is the fifth most abundant element on earth crust and its standard reduction potential is only $170 \mathrm{mV}$ above that of lithium, enabling significantly larger cell potential than that achievable with magnesium or aluminium (Table S1). Moreover, $\mathrm{Ca}^{2+}$ would hold promise for faster reaction kinetics than $\mathrm{Mg}^{2+}$ (and thus better power performance) due to its lower polarizing character. Pioneering research work by Aurbach et al. ${ }^{6}$ allowed to conclude that the electrochemical behavior of calcium electrodes in conventional organic electrolytes is surface-film controlled, as is the case for lithium ${ }^{12}$ but that calcium deposition was virtually impossible, which was attributed to the lack of calcium ion transport through the surface passivation layer formed.

In order to develop viable calcium metal anodes, the electrolyte must contain $\mathrm{Ca}^{2+}$ ions and allow reversible calcium metal plating/stripping (upon reduction/oxidation). Considering an electrode covered with a surface passivation layer, the electrodeposition of a metal M is only enabled (see Figure $\mathrm{S} 1$ ), if all the following requisites are fulfilled: 1) solvated $\mathrm{M}^{\mathrm{x}+}$ ions can diffuse/migrate within the electrolyte, 2) the desolvation energy barrier at the electrolyte/passivation layer interface is low, 3) the desolvated $\mathrm{M}^{\mathrm{x}+}$ ions can migrate through the passivation layer and 4) the energy barrier for nucleation and growth of $\mathrm{M}$ at the electrode substrate interface is low. A number of factors can influence the feasibility of one, or most commonly more, of the above processes including the the composition of the electrolyte solvent and salt, its concentration, and temperature and the nature of the substrate. These will determine the tendency of ion pairing (in turn influencing diffusion of $\mathrm{M}^{\mathrm{x}+}$ ions within the electrolyte), the desolvation energy, the 
composition of the passivation layer (and its ionic conductivity) and the nucleation energy barrier. $^{12,13,14}$

In view of the chemical similarity between calcium and magnesium, a first approach to develop calcium based batteries might have based on a concept analogous to that developed for magnesium, using electrolytes in which no surface layer is developed. ${ }^{15}$ Nonetheless, the limited redox stability and intrinsic complexity of the electrolyte formulations used in magnesium batteries prompted us to follow a radically different approach. Considering the ideal properties of any electrolyte in terms of stability, viscosity and ability to dissociate salts, we decided to reinvestigate conventional polar aprotic solvents, such as alkyl carbonates, as potential electrolytes to enable the development of calcium based batteries. These solvents can exhibit high dielectric constants $(\varepsilon)$ to dissolve salts to sufficient concentration and low viscosity to enhance ionic conductivity and display good thermal (liquidus range) and electrochemical stabilities. Such factors are at the origin of their generalized use in Li-ion cells ${ }^{16}$ and their consideration for the emerging Na-ion technology. ${ }^{17}$ In both cases, degradation reactions involving electrolyte solvents and salts take place at the interface with the highly reducing negative electrode, which result in insoluble products adhering to its surface and forming a protective solid passivation layer which enables $\mathrm{Li}^{+}$and $\mathrm{Na}^{+}$migration and is thus usually termed Solid Electrolyte Interphase (SEI). ${ }^{18,19,20}$ The intrinsic properties of solvents and the cumulated know how in the field of Li-ion and Na-ion batteries led us to the selection of a mixture of ethylene carbonate $(\mathrm{EC}, \varepsilon=89.78$ and known to build very stable passivation layers but melting at $36.4^{\circ} \mathrm{C}$ ) and propylene carbonate $\left(\mathrm{PC}, \varepsilon=64.92\right.$, melting at $\left.-48.8^{\circ} \mathrm{C}\right)$ for the electrolyte formulation. This mixture has been shown to exhibit wide liquidus range (ca. $-90^{\circ} \mathrm{C}$ to $240^{\circ} \mathrm{C}$ ) and electrochemical operation window, and to dissolve sodium salts yielding high ionic 
66

conductivities. ${ }^{21}$ The feasibility of reversible calcium electrodeposition in such electrolytes containing salts with known stable anions has been assessed through cyclic voltammetry. No redox processes in the potential window investigated (from -1.5 to $2 \mathrm{~V}$ vs. $\mathrm{Ca}^{2+} / \mathrm{Ca}_{\text {passivated }}$ ) could be detected at room temperature. Nonetheless, at higher temperatures $\left(50-100^{\circ} \mathrm{C}\right)$ and for electrolytes containing $\mathrm{Ca}\left(\mathrm{ClO}_{4}\right)_{2}$ and $\mathrm{Ca}\left(\mathrm{BF}_{4}\right)_{2}$ a redox process is observed, with intensity dependent on salt concentration and increasing with temperature (see Figure 1). No similar process was observed in any of the experiments carried out with $\mathrm{Ca}(\mathrm{TFSI})_{2}$.

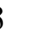

4
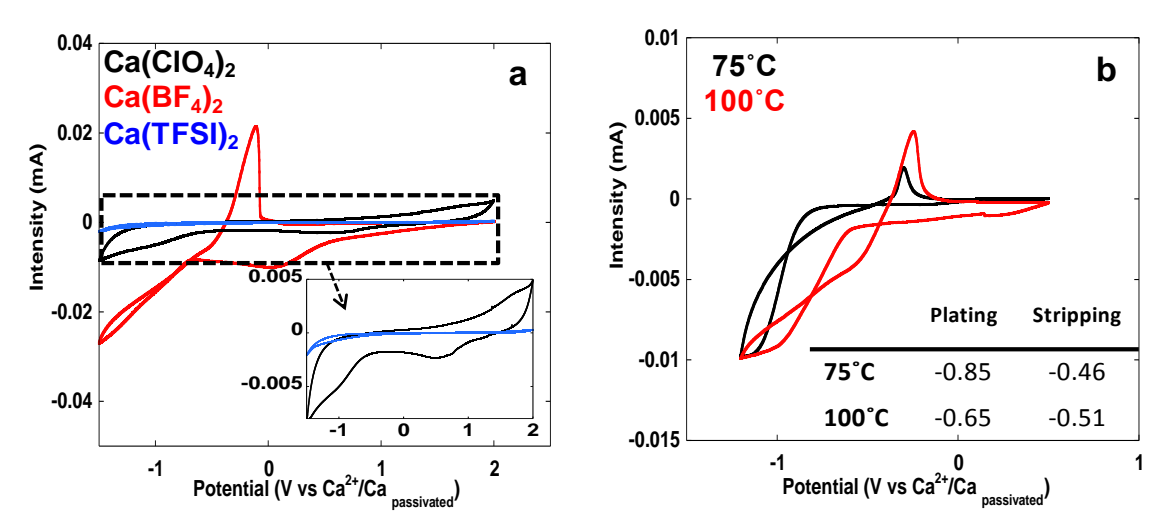

8

9

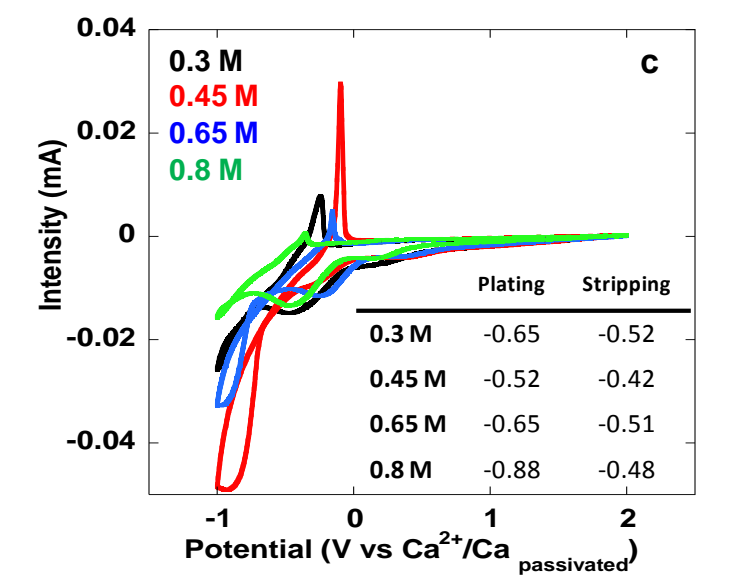

Figure 1. Cyclic voltammograms of EC:PC based electrolytes ( $0.5 \mathrm{mV} / \mathrm{s}$ scan rate) with (a) $0.3 \mathrm{M}$ concentration of different salts at $100^{\circ} \mathrm{C}$, (b) with $0.65 \mathrm{M} \mathrm{Ca}\left(\mathrm{BF}_{4}\right)_{2}$ at $75^{\circ} \mathrm{C}$ or $100^{\circ} \mathrm{C}$ and (c) with diverse $\mathrm{Ca}\left(\mathrm{BF}_{4}\right)_{2}$ concentrations from $0.3 \mathrm{M}$ to $0.8 \mathrm{M}$ at $100^{\circ} \mathrm{C}$. Insets depict an expanded scale for (a) and onset potentials for the redox process observed in (b) and (c). 
While the reversibility of this redox process is poor for the electrolytes containing $\mathrm{Ca}\left(\mathrm{ClO}_{4}\right)_{2}$, (inset in Figure 1a) voltammograms typical of reversible metal plating/stripping are observed in the case of $\mathrm{Ca}\left(\mathrm{BF}_{4}\right)_{2}$. The onset potential depends on both the temperature and salt concentration, with the smaller differences between oxidation and reduction $(0.10 \mathrm{~V})$ being found for $0.45 \mathrm{M}$ $\mathrm{Ca}\left(\mathrm{BF}_{4}\right)_{2}$ at $100^{\circ} \mathrm{C}$ (Figures $1 \mathrm{~b}$ and $\left.1 \mathrm{c}\right)$.

In order to ascertain whether the reversible redox process observed in electrolytes containing $\mathrm{Ca}\left(\mathrm{ClO}_{4}\right)_{2}$ and $\mathrm{Ca}\left(\mathrm{BF}_{4}\right)_{2}$ was due to calcium metal plating/stripping, copper substrate disks were polarized at low potential (between -1 and $-1.5 \mathrm{~V}$ vs. $\mathrm{Ca}^{2+} / \mathrm{Ca}$ passivated for $200 \mathrm{~h}$ ) and $75^{\circ} \mathrm{C}$ and further characterized. After disassembling the electrochemical cells, grey deposits are visible that are thicker for $\mathrm{Ca}\left(\mathrm{BF}_{4}\right)_{2}$ containing electrolytes. This is in agreement with the much larger current being observed in cyclic voltammograms and also consistent with scanning electron microscopy images (see Figures 2 and $\mathrm{S} 2$ ). The deposit grown using $\mathrm{Ca}\left(\mathrm{BF}_{4}\right)_{2}$ was dense and thick enough to be scratched from the substrate and sealed inside a borosilicate capillary to perform synchrotron radiation diffraction. The corresponding pattern does exhibit reflexions corresponding to $\mathrm{Ca}$ metal and $\mathrm{CaF}_{2}$ as major phases. Rietveld refinements allow determining that these are present in equimolar ratios with crystallite sizes close to $15 \mathrm{~nm}$ in both cases (Figure 2c). These results confirm that the deposit contains calcium metal and that the redox process observed does indeed correspond to reversible calcium plating/stripping, which is possible in conventional alkyl carbonate electrolytes under our operation conditions. $\mathrm{CaF}_{2}$ is certainly derived from electrolyte decomposition and most likely part of the surface passivation layer, in agreement with similar studies conducted on Li-ion batteries reporting presence of LiF in passivation layers formed in $\mathrm{LiBF}_{4}$ containing electrolytes. ${ }^{22}$ As scratching of the deposits did not enable its full quantitative transfer to the capillary (residues always remain which lead to an 
overestimation of the SEI products present on the surface), energy dispersive X-ray analysis (EDX) on the as prepared deposits enabled a better estimate of the deposit composition, which shows large amounts of $\mathrm{Ca}$ and $\mathrm{F}$ and minor $\mathrm{C}$ and $\mathrm{O}$ contents $(<10 \%)$. Using this technique, the relative amount of $\mathrm{Ca}$ and $\mathrm{CaF}_{2}$ can be deduced from the $\mathrm{Ca} / \mathrm{F}$ ratios averaged on different parts of the deposit. The molar $\mathrm{Ca} / \mathrm{CaF}_{2}$ ratio for the deposit grown and $200 \mathrm{~h}$ at $75^{\circ} \mathrm{C}$ was found to be $2.4(\mathrm{Ca} / \mathrm{F}=1.7)$ which is, as expected, higher than the value measured by diffraction. In order to assess the influence of time and temperature on the deposit composition EDX was also carried out on deposits grown at $100^{\circ} \mathrm{C}$ for $200 \mathrm{~h}$ and at $100^{\circ} \mathrm{C}$ for $72 \mathrm{~h}$ and the molar $\mathrm{Ca} / \mathrm{CaF}$ ratios were respectively found to be $5.4(\mathrm{Ca} / \mathrm{F}=3.2)$ and $2(\mathrm{Ca} / \mathrm{F}=1.5)$. Such values are in agreement with a continuous growth of the relative amount of calcium metal with time which is consistent with the SEI being formed at the beginning of reduction. The fact that deposits grown at $100^{\circ} \mathrm{C}$ exhibit larger amounts of calcium than those grown at $75^{\circ} \mathrm{C}$ for the same deposition time $\left(200^{\circ} \mathrm{C}\right)$ points at temperature enhancing the kinetics of electroplating while having limited effect on the electrolyte decomposition to form the SEI. The deposits grown on $\mathrm{Ca}\left(\mathrm{ClO}_{4}\right)_{2}$ were very thin and consisted of discrete micrometric grains that even for long deposition times (200h) did not fully cover the substrate (see Figure S2). Energy dispersive X-ray analysis (EDX) indicates that they contain calcium, carbon, oxygen and chlorine and its infrared spectrum does exhibit a band at $3642 \mathrm{~cm}^{-1}$ which is indicative of the presence of $\mathrm{Ca}(\mathrm{OH})_{2}$, in agreement with the findings reported by Aurbach et al. ${ }^{6}$ when studying the composition of the passivation layer for Ca metal when stored in PC. Since the relative amount of $\mathrm{Ca}$ in the deposits made using $\mathrm{Ca}\left(\mathrm{ClO}_{4}\right)_{2}$ is found to increase with temperature from $19 \%$ at $75^{\circ} \mathrm{C}(200 \mathrm{~h})$ to $55 \%$ at $100^{\circ} \mathrm{C}(200 \mathrm{~h})$, it seems reasonable to conclude that $\mathrm{Ca}$ metal deposition does also take place in this electrolyte but to a much lower extent than in the case of $\mathrm{Ca}\left(\mathrm{BF}_{4}\right)_{2}$. 


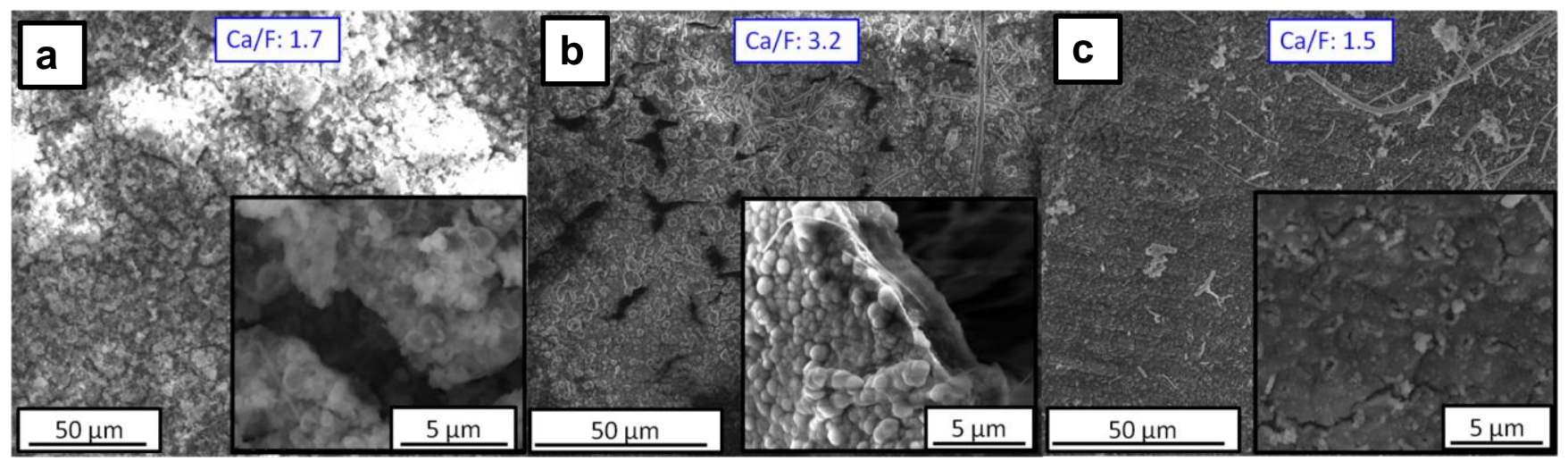

139

Figure 2. Typical SEM micrographs of deposits obtained in $0.3 \mathrm{M} \mathrm{Ca}\left(\mathrm{BF}_{4}\right)_{2} \mathrm{EC}: \mathrm{PC}$ at $-1.5 \mathrm{~V} \mathrm{vs.} \mathrm{Ca}^{2+} / \mathrm{Ca}$ passivated. (a) at $75^{\circ} \mathrm{C}$ for $200 \mathrm{~h}$, (b) at $100^{\circ} \mathrm{C}$ for $200 \mathrm{~h}$ and (c) at $100^{\circ} \mathrm{C}$ for $72 \mathrm{~h}$. The $\mathrm{Ca} / \mathrm{F}$ ratios determined by EDX

151 are indicated. (d) depicts the Rietveld refinement (black line) of the synchrotron X-ray diffraction pattern (red

152 circles) corresponding to a deposit grown at $75^{\circ} \mathrm{C}$ for $200 \mathrm{~h}$ after scratching from the substrate and sealing in a

153 borosilicate capillary. Vertical colour ticks denote Bragg positions corresponding to the different phases identified.

154 The inset shows an expanded view of the low angle peaks corresponding to $\mathrm{Ca}$ and $\mathrm{CaF}_{2}$, that are present in

155 equimolar amounts. Traces of $\mathrm{Cu}(6 \mathrm{wt} . \%)$ and $\mathrm{Fe}(3 \mathrm{wt} . \%)$ are detected, due to scratching the deposit from the

156 copper substrate and stainless steel current collector. 
157 One may thus conclude that the higher calcium plating/stripping efficiency observed using

$158 \mathrm{Ca}\left(\mathrm{BF}_{4}\right)_{2}$ is related to the surface layer composition enabling an easier migration of $\mathrm{Ca}^{2+}$ ions and that both the SEI composition and the operation temperature are crucial to achieve suitable reaction kinetics. The plating/stripping intensity for $\mathrm{Ca}\left(\mathrm{BF}_{4}\right)_{2}$ at $100^{\circ} \mathrm{C}$ was found to be concentration dependent and increase from $0.3 \mathrm{M}$ to $0.45 \mathrm{M}$ and decrease above this value (see Figure 1c). This maximum value is correlated to ionic conductivity being highest at $0.45 \mathrm{M}$ arising from optimum effective charge carrier concentration (limited ion pairing, see Walden plot in Figure S3). The stability of the calcium deposition/stripping process upon cycling was assessed for $0.45 \mathrm{M} \mathrm{Ca}\left(\mathrm{BF}_{4}\right)_{2}$ in $\mathrm{EC}: \mathrm{PC}$ operating at $100^{\circ} \mathrm{C}$. Deposits obtained after polarization at low potential $\left(-1.2 \mathrm{~V}\right.$ vs. $\left.\mathrm{Ca}^{2+} / \mathrm{Ca}_{\text {passivated }}\right)$ were further characterized by cyclic voltammetry (see Figure 3) for more than 30 cycles. The magnitude of the current upon reduction decreases in the initial stage of the experiment reaching a steady value afterwards, which is in agreement with the gradual formation of the passivation layer in the first cycles. The amount of charge associated to calcium stripping (oxidation) is found to be ca. $20 \mathrm{mC}(10 \mu \mathrm{g} \mathrm{Ca})$ and to remain almost constant vs. cycle number (see inset in Figure 3) which confirms the stability of the plating/stripping process upon cycling and set the basis for reversible operation of calcium anodes.

While it is clear that future research should aim at reducing operation temperature as much as possible, our results do indicate viability of calcium anodes working at $100^{\circ} \mathrm{C}$. Indeed symmetric $\mathrm{Ca} / / \mathrm{Ca}$ cells with $0.45 \mathrm{M} \mathrm{Ca}\left(\mathrm{BF}_{4}\right)_{2}$ in $\mathrm{EC}: \mathrm{PC}$ as electrolyte do exhibit good cyclability at $100^{\circ} \mathrm{C}$ (see Figure $\mathrm{S} 4$ for comparison with $\mathrm{Li} / / \mathrm{Li}$ cells using standard electrolytes at room temperature) with ohmic drop $\sim 50 \mathrm{mV}$. Infrared spectra of electrodeposited calcium electrodes after plating (see Figure 3b) enable to detect a very small amount of hydroxide (band 
$181\left(1420 \mathrm{~cm}^{-1}\right), \mathrm{C}=\mathrm{O}$ symmetric stretching $\left(\sim 1300 \mathrm{~cm}^{-1}\right), \mathrm{C}-\mathrm{O}$ stretching $\left(\mathrm{ca} .1100 \mathrm{~cm}^{-1}\right)$ and $\mathrm{CO}_{3}$

182 bending $\left.\left(\sim .800 \mathrm{~cm}^{-1}\right)\right)$. The spectrum is not modified after stripping which indicates a good

183 stability of the SEI while also indirectly proving its permeability to $\mathrm{Ca}^{2+}$ ions.
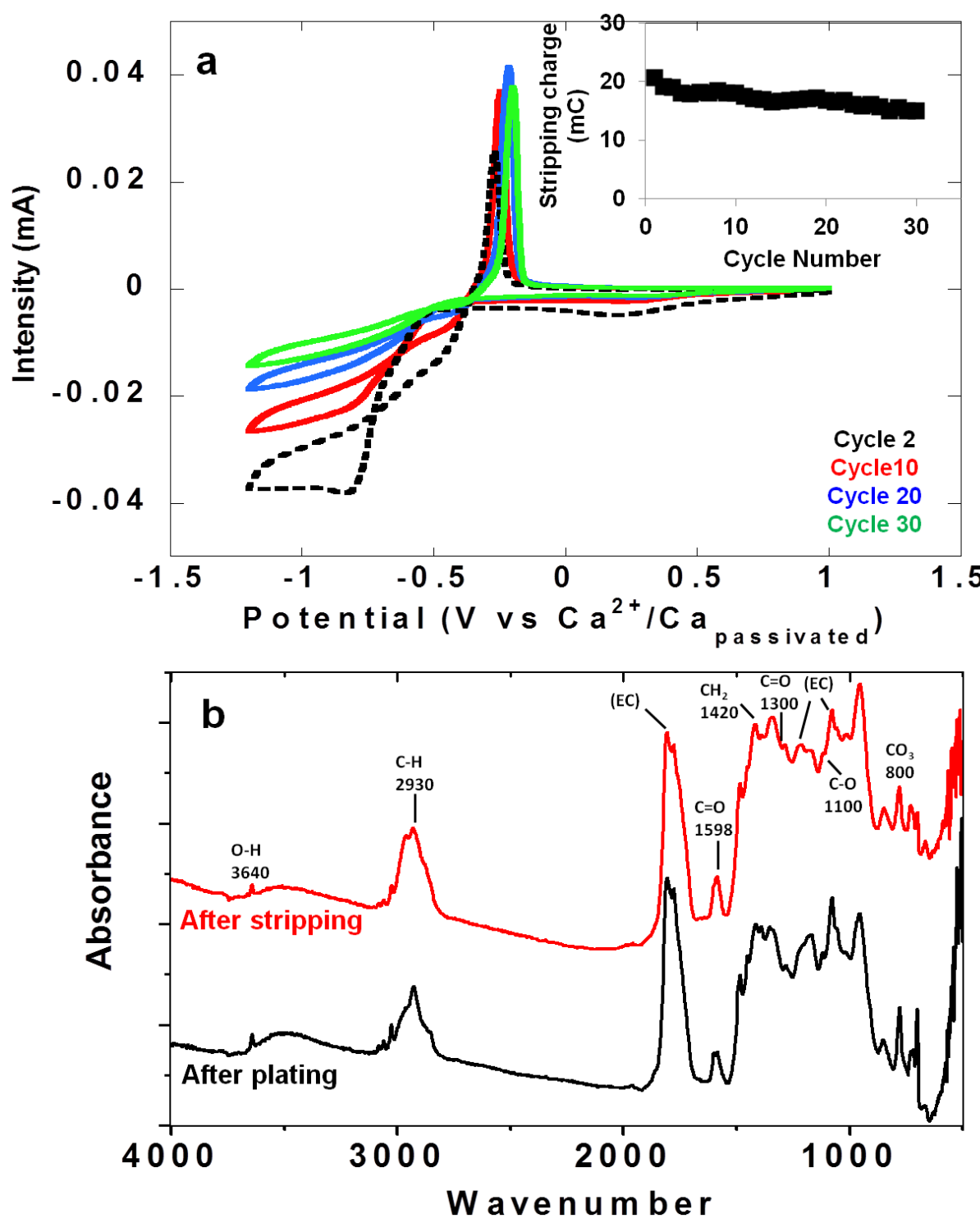

Figure 3. Cyclic voltammograms $\left(100^{\circ} \mathrm{C}, 0.2 \mathrm{mV} / \mathrm{s}\right.$ ) of a calcium deposit (grown by potentiostatic electrodeposition at $-1.2 \mathrm{~V}$ vs $\left.\mathrm{Ca}^{2+} / \mathrm{Ca}_{\text {passivated }}, 5 \mathrm{~h}, 100^{\circ} \mathrm{C}\right)$ in $0.45 \mathrm{M} \mathrm{Ca}\left(\mathrm{BF}_{4}\right)_{2} \mathrm{EC}: \mathrm{PC}$ electrolytes (a) and corresponding infra-red

187 spectra on calcium deposits after plating and stripping $\left(-0.1 \mathrm{~V} \mathrm{vs} \mathrm{Ca}^{2+} / \mathrm{Ca}_{\text {passivated }}, 5 \mathrm{~h}, 100^{\circ} \mathrm{C}\right)(\mathrm{b})$. The inset displays the evolution of the charge associated with calcium metal stripping upon cycling. 
189 Since the well known stability of the electrolyte used at high potentials is maintained at $100^{\circ} \mathrm{C}$

190 (see Figure S5) with $0.45 \mathrm{M} \mathrm{Ca}\left(\mathrm{BF}_{4}\right)_{2}$ in EC:PC exhibiting a potential stability window of about

$1914 \mathrm{~V}$ (between $-0.5 \mathrm{~V}$ and $3.5 \mathrm{~V}$ vs $\mathrm{Ca}^{2+} / \mathrm{Ca}_{\text {passivated }}$ ), no compatibility issues with high voltage positive

192 electrode materials are expected. The findings presented herein thus open the way to exploratory

193 screening and testing of potential cathode materials which would reversibly insert and deinsert

194 calcium and achieve proof-of-concept for the Ca-based rechargeable battery. We are confident

195 that our results will serve as the basis to explore alternative far-reaching research avenues which

196 will soon turn these optimistic academic prospects into a new energy storage technology.

197

198

199

200

201

202

203

204

205

206

207

208

209

210

211

Acknowledgments: Authors are grateful to Dr. François Fauth for his assistance during data collection at ALBA synchrotron. The authors thank the Toyota Battery Research division at Higashi Fuji (M6) for his financial support.

Author Contributions M.R.P. and F.B. conceived and coordinated the study, A.P. designed, performed and analysed the electrochemical experiments and C.F. analysed diffraction data. All authors discussed the results and A.P. and M.R.P. wrote the paper with contributions of all authors.

\section{Competing financial interests}

The authors declare no competing financial interests.

\section{References}


1. Muldoon, J. Quest for Nonaqueous Multivalent Secondary Batteries: Magnesium and Beyond, Chem. Rev. 114, 11683-11720 (2014)

2. Amatucci, G.G. et al. Investigation of Yttrium and Polyvalent Ion Intercalation into Nanocrystalline Vanadium Oxide. J. Electrochem. Soc 148, A940-A950 (2001)

3. Aurbach, D. et al. Prototype systems for rechargeable magnesium batteries Nature, 407, 724$727(2000)$

4. Yoo, H.D. et al. Mg rechargeable batteries: an on-going challenge, Energy Environ. Sci. 6 , $2265-2279(2013)$

5. Muldoon, J. et al. Electrolyte roadblocks to a magnesium rechargeable battery. Energy Environ. Sci. 5, 5491-5950 (2012)

6. Aurbach,D., Skaletsky, R., Gofer, Y. The Electrochemical Behavior of Calcium Electrodes in a Few Organic Electrolytes. J. Electrochem. Soc. 138, 3536-3545 (1991)

7. Sammells, A.F., Schumacher, B. Secondary Calcium Solid Electrolyte High Temperature Battery. J. Electrochem. Soc. 133, 235-236 (1986)

8. Staniewicz, R.J. A Study of the Calcium-Thionyl Chloride Electrochemical System. J. Electrochem. Soc. 127,782-789 (1980)

9. Hayashi, M., Arai, H., Ohtsuka, H., Sakurai, Y. Electrochemical characteristics of calcium in organic electrolyte solutions and vanadium oxides as calcium hosts. J. Power Sources 119-121, $617-620(2003)$

10. See, K.A. et al. A High Capacity Calcium Primary Cell Based on the Ca-S System. Adv. Energy Mater. 3, 1056-1061(2013) 
11. M. C. Lin et al. An ultrafast rechargeable aluminium-ion battery. Nature 520, 325 (2015).

12. Xu, K. Electrolytes and Interphases in Li-ion Batteries and Beyond, Chem. Rev. 114, 11503$11618(2014)$

13. Marcus, R.A. On the Theory of Oxidation-Reduction Reactions Involving Electron Transfer.

I. J. Chem. Phys. 24, 966 (1956)

14. Budevski, E., Staikov, G., Lorenz, W.J. Electrochemical Phase Formation and Growth, VCH, New York, 1996

15. Gofer, Y. et al. Improved Electrolyte Solutions for Rechargeable Magnesium Batteries. Electrochem. Solid State Lett. 9, A257-A260 (2006)

16. Xu, K. Nonaqueous Liquid Electrolytes for Lithium-Based Rechargeable Batteries. Chem. Rev. 104, 4303-4417 (2004)

17. Ponrouch, A. et al. Non-Aqueous Electrolytes for Sodium-Ion Batteries J. Mater. Chem. A 3, $22-42(2015)$

18. Peled, E., Menahem, C., Bar Tow, D., Melman, A. The Electrochemical Behavior of Alkali and Alkaline Earth Metals in Nonaqueous Battery Systems-The Solid Electrolyte Interphase Model J. Electrochem. Soc. 143, L4 (1996)

19. Aurbach, D. Review of selected electrode-solution interactions which determine the performance of Li and Li ion batteries J. Power Sources 89, 206 (2000)

20. Xu, K., von Cresce, A. Interfacing electrolytes with electrodes in Li ion batteries J. Mater.

Chem. 21, 9849 (2011) 
21. Ponrouch, A., Marchante, E., Courty, M., Tarascon, J.M., Palacín, M.R. In search of an optimized electrolyte for Na-ion batteries. Energy Environ. Sci. 5, 8572-8583 (2012)

22. Nie, M., Lucht, B.L. Role of lithium salt on solid electrolyte interface (SEI) formation and structure in lithium ion batteries. J. Electrochem. Soc. 161, A1001-A1006 (2014)

\section{METHODS}

Materials All investigated electrolytes consist of a calcium salt $\mathrm{Ca}(\mathrm{TFSI})_{2}(\mathrm{Calcium}$ Bis(trifluoromethanesulfonimide), $\left(\mathrm{Ca}\left(\mathrm{ClO}_{4}\right)_{2}\right.$ or $\mathrm{Ca}\left(\mathrm{BF}_{4}\right)_{2}$ (Alfa Aesar or Sigma Aldrich, $98 \%$ ) dissolved in a mixture 50/50 wt\% mixture of propylene carbonate (PC hereafter, Aldrich, anhydrous, 99.7\%) and ethylene carbonate (EC, Aldrich, anhydrous, 99.0\%). Solvents were used as received while salts were vacuum dried at moderate temperatures $\left(100^{\circ} \mathrm{C}\right)$ prior to use.

Electrolyte characterization The water content in all electrolytes was measured by Karl-Fisher titration and found to be lower than $40 \mathrm{ppm}$. For sake of comparison, ionic conductivity and viscosity were also measured for the standard alkyl carbonate based electrolyte used in Li-ion batteries (i.e. $1 \mathrm{M} \mathrm{LiPF}_{6}$ in EC:DMC 1:1 Merck, with DMC denoting dimethylcarbonate). The ionic conductivity was determined using the complex impedance method in the temperature range of $0-100{ }^{\circ} \mathrm{C}$ (HUBER thermostatic bath MPC-K6). The samples were thermally equilibrated at each temperature for at least $1 \mathrm{~h}$ prior to the measurements. The electrolytes were confined between two stainless steel electrodes using a Teflon ring spacer in a constant-volume tight cylindrical cell (9 $\mathrm{mm}$ electrode diameter and $1 \mathrm{~mm}$ fixed electrode distance) assembled 
inside an argon filled glovebox. The cell constant, determined with a $0.1 \mathrm{M} \mathrm{KCl}$ standard solution, was $0.16 \mathrm{~cm}^{-1}$. Viscosities were measured with a RheoStress RS600 Rheometer (HAAKE) at temperatures ranging from 25 to $100^{\circ} \mathrm{C}$.

Electrochemistry Cyclic voltamperometry was performed in three-electrode Swagelok cells ${ }^{22}$ using calcium metal (Alfa Aesar, 98\%) as counter and reference electrodes. The potential of this pseudo reference electrode was calibrated by performing cyclic voltammetries in $10 \mathrm{mM}$ ferrocene containing electrolytes. When compared to standard redox potential of the $\mathrm{Ca}^{2+} / \mathrm{Ca}^{0}$ vs. NHE, a negative potential shift was recorded and found to vary between 0.5 and $1 \mathrm{~V}$ for $\mathrm{Ca}\left(\mathrm{BF}_{4}\right)_{2}$ based electrolytes depending on salt concentration $(0.3 \mathrm{M}-0.65 \mathrm{M})$ and temperature $\left(25^{\circ} \mathrm{C}\right.$ $\left.100^{\circ} \mathrm{C}\right)$; and to be close to $1.5 \mathrm{~V}$ for $0.3 \mathrm{M} \mathrm{Ca}\left(\mathrm{ClO}_{4}\right)_{2}$ at $25^{\circ} \mathrm{C}$. Similar shifts have been reported for other metals when covered with a passivation layer resulting from electrolyte decomposition, which should in a strict sense be considered as pseudo reference electrodes. ${ }^{6,22}$ For sake of clarity all potentials reported are measured values and denoted as $\mathrm{V}$ vs. $\mathrm{Ca}^{2+} / \mathrm{Ca}$ passivated in the manuscript. Working Electrode (WE) plungers were made of stainless steel except for experiments with high cut off potential ( $4 \mathrm{~V}$ vs. $\left.\mathrm{Ca}^{2+} / \mathrm{Ca}_{\text {passivated }}\right)$ in which aluminum was used. Unless otherwise specified, the applied sweep rate was typically $0.5 \mathrm{mV} / \mathrm{s}$. All electrochemical tests were performed using a Bio-Logic VMP3 potentiostat assembling twin cells to assess reproducibility of results. Electrochemical Impedance Spectroscopy (EIS) measurements were performed with $20 \mathrm{mV}$ perturbation amplitudes $(500 \mathrm{kHz}-0.5 \mathrm{~Hz})$.

Characterization of electrodeposits Scanning Electron Microscopy (SEM) studies were performed using a Quanta 200 ESEM FEG FEI microscope equipped with an energy-dispersive 
X-ray spectrometer (EDX). Synchrotron X-ray powder diffraction (SXRPD) at RT was measured at MSPD beamline ${ }^{22}$ of ALBA synchrotron (Cerdanyola del Vallès, SPAIN). Electrochemical cells were dismantled inside an Ar filled glove box and deposits scratched and introduced in a borosilicate glass capillary ( $0.3 \mathrm{~mm}$ in diameter). By means of the double $\mathrm{Si}$ (111) crystal monochromator, a short wavelength was selected and calibrated using Si NIST $(\lambda=0.620041 \AA)$. The capillary rotated during data collection, which was carried out using a fast mythen detector. FullProf_suite ${ }^{22}$ programs were used for the Rietveld refinement of collected patterns. In order to determine the size of the crystallites, the instrumental resolution function was determined by measuring $\mathrm{Na}_{2} \mathrm{Ca}_{3} \mathrm{Al}_{2} \mathrm{~F}_{14}{ }^{22}$ as standard. Four phases were clearly indentified in the pattern: $\mathrm{Ca}$, $\mathrm{CaF}_{2}, \mathrm{Cu}$ and $\mathrm{Fe}$, the last two present in minor amounts and arising from scratching the substrate and current collector. The agreement parameters reveal the quality of the refinement $\left(\chi^{2}=1.96\right.$, $\mathrm{R}_{\mathrm{wp}}=14.6 \%$ and Bragg R-factors being 4.4, 2.8, 2.8 and 5.3\% respectively for the four aforementioned phases). Semi-quantitative analysis (i.e. taking into account only the crystalline part of the four considered phases) renders weight fractions of 28, 63, 6 and 3\% respectively. The SEI formed on Ca metal anodes was analyzed by infrared spectroscopy on a Vertex 70 FTIR Spectrometer using a praying mantis diffuse reflectance accessory (HARRICK) in order to prevent any air exposure 


\title{
Supplementary information
}

\section{Towards a calcium-based rechargeable battery}

\author{
A. Ponrouch, C. Frontera, F. Bardé, M.R. Palacín
}

\section{Supplementary table}

Table S1. Properties of some metals that can be used as battery anodes: radius of the corresponding ion, standard reduction potential, electrochemical capacity, density and abundance in crustal rocks.

\begin{tabular}{|c|c|c|c|c|c|}
\hline Element & $\begin{array}{l}\text { Abundance in } \\
\text { crustal rocks } \\
\quad(p p m)^{1}\end{array}$ & $\begin{array}{r}\text { Density } \\
\left(\mathrm{g} / \mathrm{cm}^{3}\right)\end{array}$ & $E^{0}$ vs. NHE (Volts) ${ }^{2}$ & $\begin{array}{l}\text { Electrochemical } \\
\text { Capacity }(\mathrm{Ah} / \mathrm{g})\end{array}$ & $\begin{array}{c}\text { Ionic Radius } \\
(\AA)^{3}\end{array}$ \\
\hline Lithium & 18 & 0.53 & -3.04 & 3.86 & 0.76 \\
\hline Sodium & 22700 & 0.97 & -2.71 & 1.17 & 1.02 \\
\hline Magnesium & 27640 & 1.74 & -2.37 & 2.21 & 0.72 \\
\hline Calcium & 46600 & 1.54 & -2.87 & 1.34 & 1.00 \\
\hline Aluminium & 83000 & 2.70 & -1.66 & 2.98 & 0.53 \\
\hline
\end{tabular}




\section{Supplementary Figures}

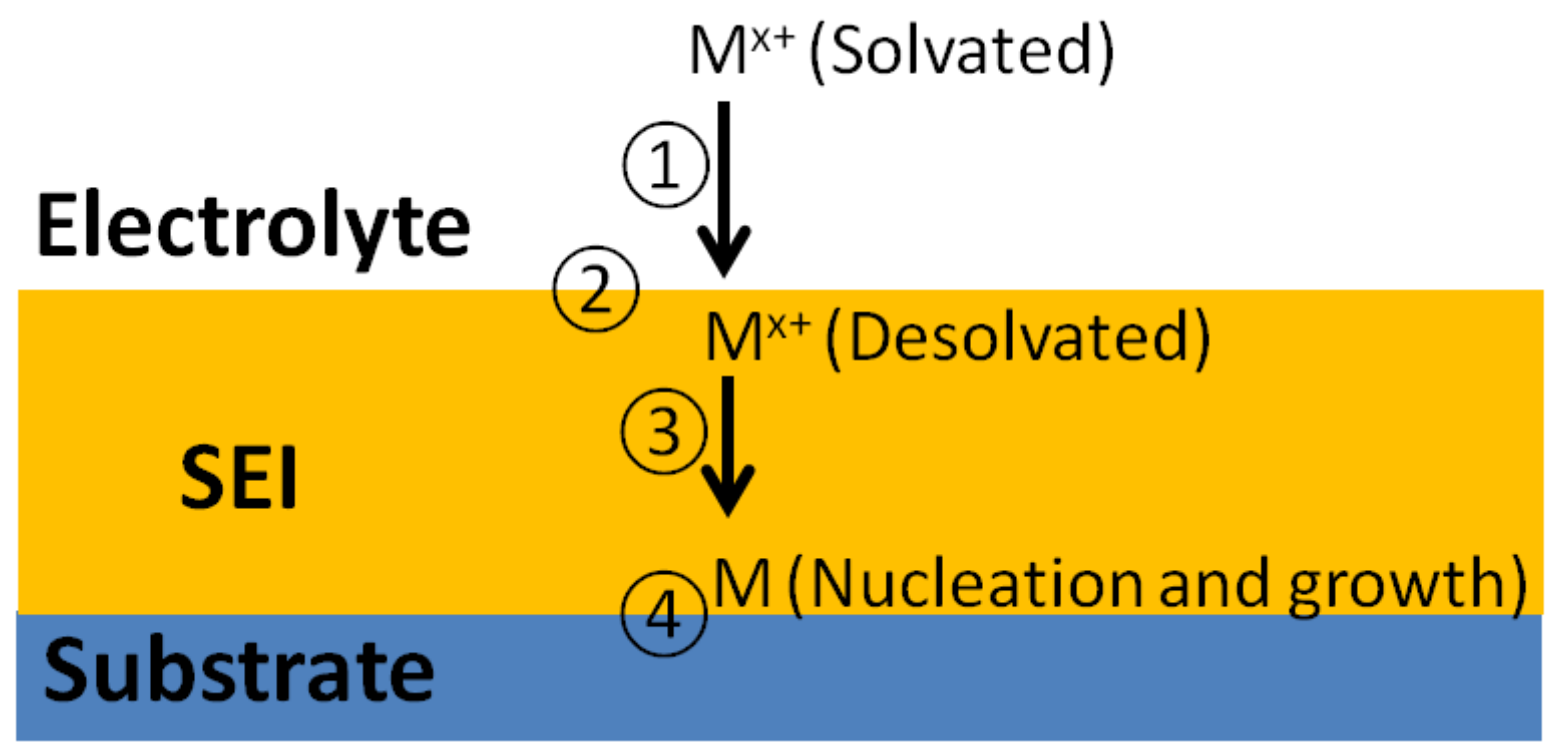

Figure S1. Schematic representation of the four main subsequent steps involved in the global process of electrodepositing a metal on the surface of an electrode covered with a passivation layer (or Solid Electrolyte Interphase, denoted as SEI). 

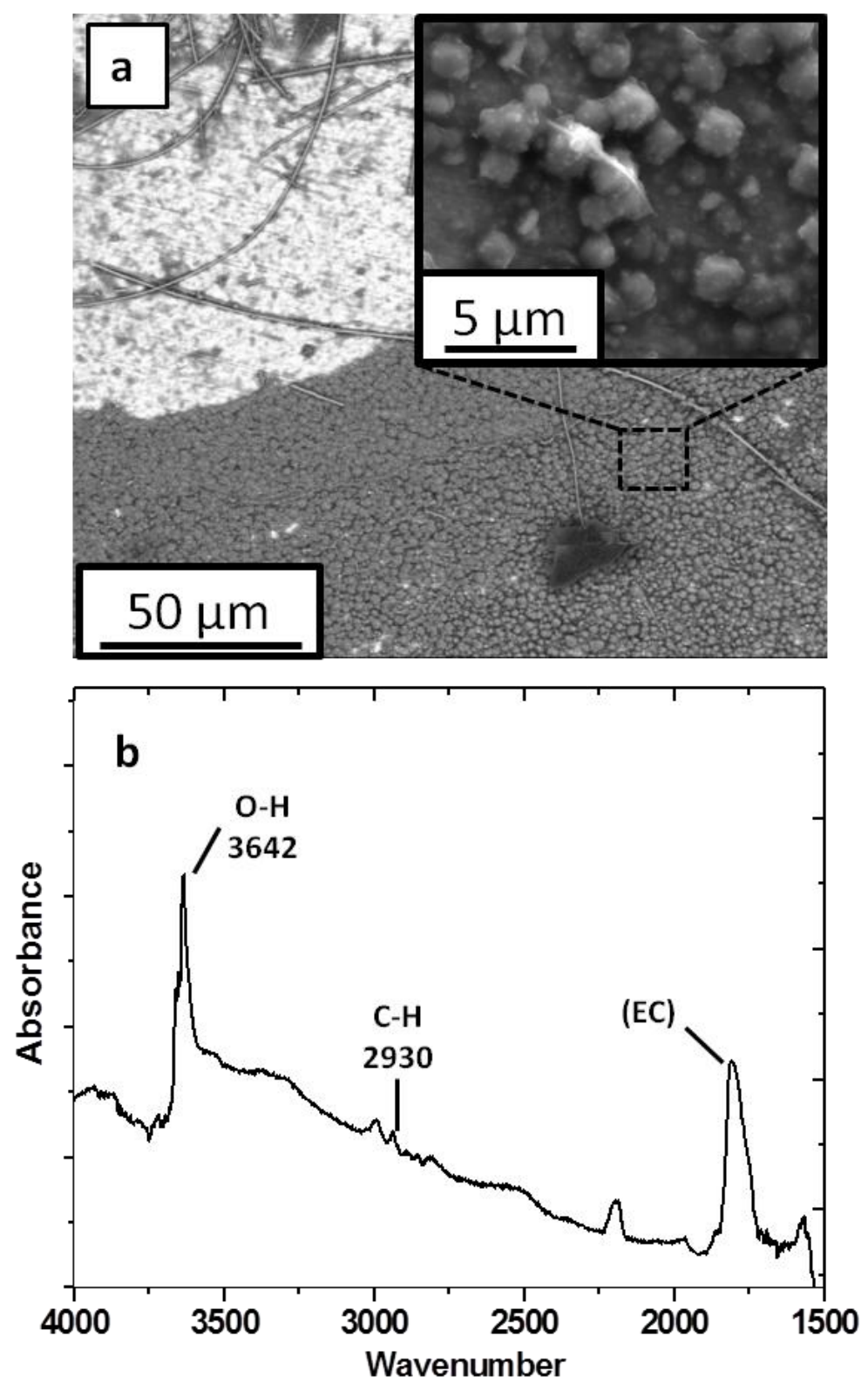

Figure S2. (a) Typical SEM micrograph and (b) Infrared spectrum of a deposit obtained in $0.3 \mathrm{M} \mathrm{Ca}\left(\mathrm{ClO}_{4}\right)_{2} \mathrm{EC}: \mathrm{PC}$ at $-1.5 \mathrm{~V}$ vs. $\mathrm{Ca}^{2+} / \mathrm{Ca}_{\text {passivated. }}$ at $75^{\circ} \mathrm{C}$ for $200 \mathrm{~h}$. The band at $3642 \mathrm{~cm}^{-1}$ indicates the presence of hydroxide anions. 


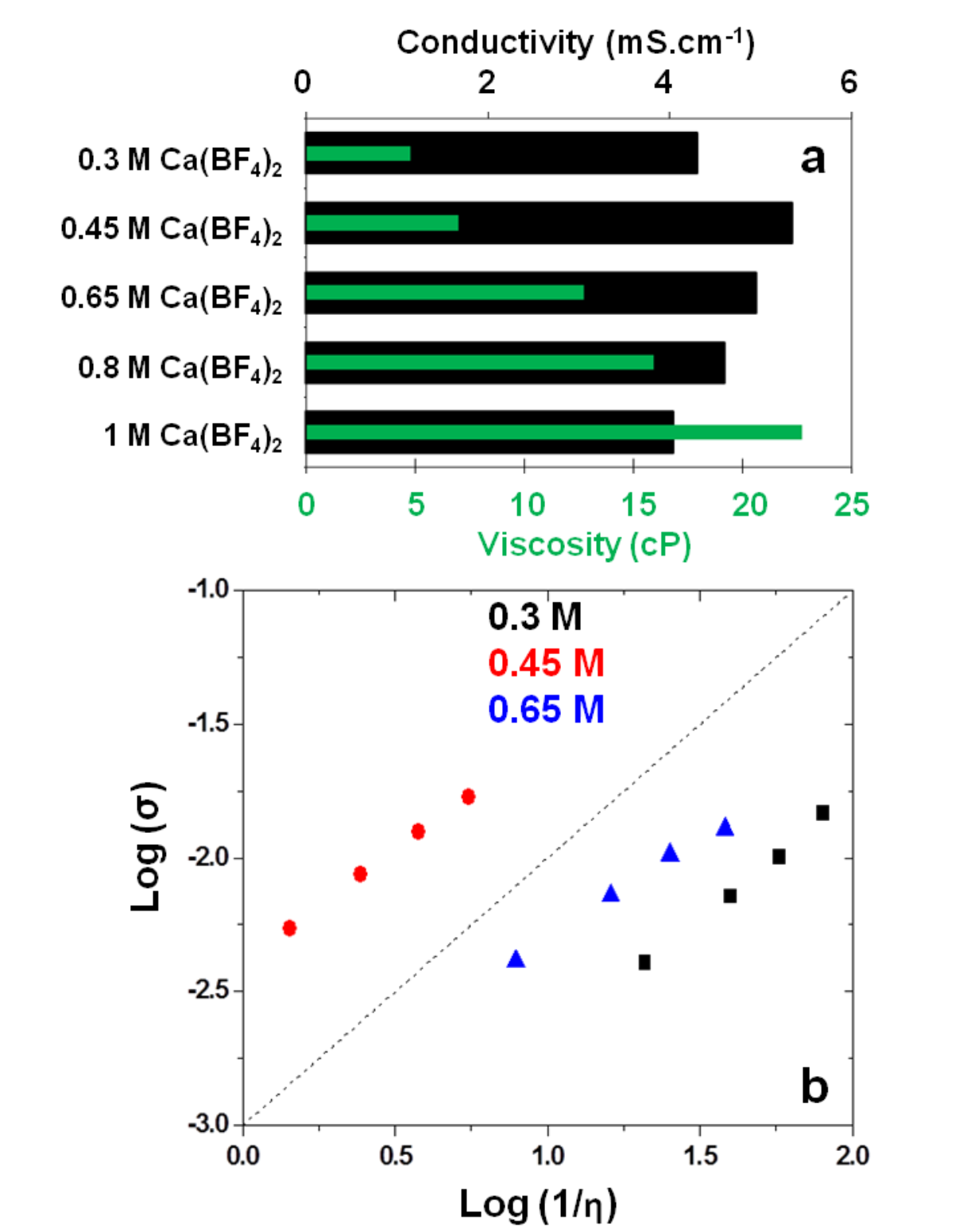

Figure S3. (a) Ionic conductivity at $25^{\circ} \mathrm{C}$ (black bars and upper $\mathrm{x}$ axis) and viscosity (green bars and lower $\mathrm{x}$ axis) for electrolytes with various $\mathrm{Ca}\left(\mathrm{BF}_{4}\right)_{2}$ salt concentrations in $\mathrm{EC}: \mathrm{PC}(\mathrm{b})$ Walden plot resulting from measurements of viscosity and ionic conductivity for electrolytes with diverse $\mathrm{Ca}\left(\mathrm{BF}_{4}\right)_{2}$ concentrations and temperatures ranging from 20 to $100^{\circ} \mathrm{C}$. 


\section{Evolution of ionic conductivity and viscosity with temperature and concentration}

The ionic conductivities of $0.3 \mathrm{M} \mathrm{Ca}\left(\mathrm{ClO}_{4}\right)_{2}$ and $\mathrm{Ca}\left(\mathrm{BF}_{4}\right)_{2}$ in $\mathrm{EC}: \mathrm{PC}$ at room temperature are similar (ca. 6 and $4 \mathrm{mS} / \mathrm{cm}$ respectively) and viscosities are in both cases close to $4.5 \mathrm{cP}$. These values differ significantly from those measured for conventional $\mathrm{Li}$-ion commercial battery electrolytes (12 mS/cm, $2 \mathrm{cP}$ for $1 \mathrm{M} \mathrm{LiPF}_{6}$ dissolved in $\mathrm{EC}: \mathrm{DMC}$ at room temperature), which points at a limited diffusion of solvated $\mathrm{Ca}^{2+}$ ions in the above mentioned dissolutions.

The evolution of viscosity and ionic conductivity with salt concentration and temperature was studied for $\mathrm{Ca}\left(\mathrm{BF}_{4}\right)_{2}$ (see Figure S3). At room temperature, the viscosity was found to significantly increase with concentration, as expected, up to $23 \mathrm{cP}$ for $1 \mathrm{M}$ electrolytes. In contrast, the ionic conductivity increases with concentration from $0.3 \mathrm{M}$ to $0.45 \mathrm{M}$ but decreases above this value. This behavior is well known for Li-ion battery electrolytes and is related to a larger amount of dissociated ions resulting from enhanced salt concentration followed by the decline of ion mobility due to the rise of viscosity and ion pairing. ${ }^{4}$ Ion pair formation is known to be temperature dependent and to take place to a larger extent in solutions containing divalent ions due to stronger coulombic interactions with the anions. This is evident from Bjerrum's treatment, ${ }^{5}$ which gives the critical distance for ion pair formation, $\mathrm{q}$

$\mathrm{q}=\left|\mathrm{z}_{\mathrm{i}} \mathrm{z}_{\mathrm{j}}\right| \mathrm{e}^{2} /\left(8 \pi \epsilon_{0} \in \mathrm{k} T\right)$

where $\mathrm{z}_{\mathrm{i}}, \mathrm{z}_{\mathrm{j}}, \epsilon_{0}, \mathrm{k}$, and $\mathrm{T}$ denote the formal charge of anions and cations, the dielectric constant of vacuum, Boltzmann's constant, and temperature, respectively. In an ideal case with no ion pair formation, the amount of effective charge carriers is invariant with temperature. In contrast, if ion pairs exist, increasing temperature will contribute to break them. The Walden rule ${ }^{6}$

$\sigma \cdot \eta=$ constant 
where $\sigma$ is the ionic conductivity and $\eta$ the viscosity is commonly used to estimate the degree of ion pair formation in a given dissolution through the deviation from unity in the slope of the log $\sigma v s . \log 1 / \eta$ plot. Figure S3B depicts the Walden plot resulting from measurements of viscosity and ionic conductivity for electrolytes with diverse $\mathrm{Ca}\left(\mathrm{BF}_{4}\right)_{2}$ concentrations and temperatures ranging from 20 to $100^{\circ} \mathrm{C}$. Calculated slopes are ca. $0.95,0.85$ and 0.73 , respectively, for 0.3 , 0.45 and $0.65 \mathrm{M}$. Thus, significant ion pair formation takes place above $0.45 \mathrm{M}$, which enhances viscosity and decreases ionic conductivity. Therefore operation at moderate temperature is mandatory to break ion pairs and enable calcium plating/stripping.

\section{Benchmarking of electrodeposited metal electrodes: Ca vs. Li}

In order to address practical technological prospects for calcium metal anodes, their performance has been confronted to lithium metal anodes as a sort of "benchmarking test". Symmetric cells have been assembled with electrodeposited electrodes on stainless steel: calcium $(-1.2 \mathrm{~V}$ vs. $\mathrm{Ca}^{2+} / \mathrm{Ca}_{\text {passivated, }}, 80 \mathrm{~h}, 0.45 \mathrm{M} \mathrm{Ca}\left(\mathrm{BF}_{4}\right)_{2}$ in $\mathrm{EC}: \mathrm{PC}$ at $\left.100^{\circ} \mathrm{C}\right)$ and lithium $\left(-0.1 \mathrm{~V} \mathrm{vs.} \mathrm{Li}^{+} / \mathrm{Li}, 80 \mathrm{~h}, 1\right.$ $\mathrm{M} \mathrm{LiPF}_{6}$ in EC:DMC at room temperature). These cells have been tested in galvanostatic mode, which is more representative of real battery operation conditions than cyclic voltammetry experiments. Charge/discharge profiles prompt to optimism in terms of application as cyclability is comparable for the two cases with ohmic drop being below $50 \mathrm{mV}$ in all cases (though higher for $\mathrm{Ca} / / \mathrm{Ca}$ cells, see figure $\mathrm{S} 4)$. 

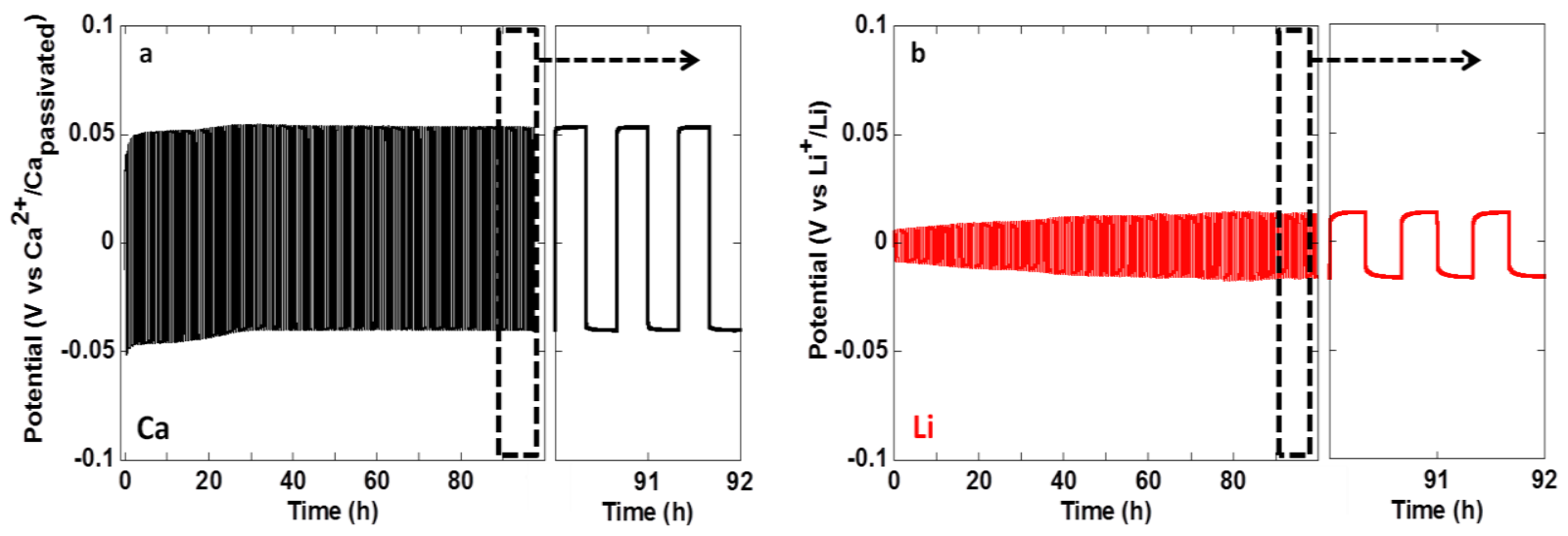

Figure S4. Charge/discharge curves $\left(50 \mu \mathrm{A} / \mathrm{cm}^{2}, 150\right.$ cycles) of (a) symmetric $\mathrm{Ca} / \mathrm{Ca}$ cells with $0.45 \mathrm{M}$ $\mathrm{Ca}\left(\mathrm{BF}_{4}\right)_{2}$ in $\mathrm{EC}: \mathrm{PC}$ at $100^{\circ} \mathrm{C}$ and (b) $\mathrm{Li} / \mathrm{Li}$ cells cycled at room temperature in $1 \mathrm{M} \mathrm{LiPF}_{6}$ in EC:DMC.

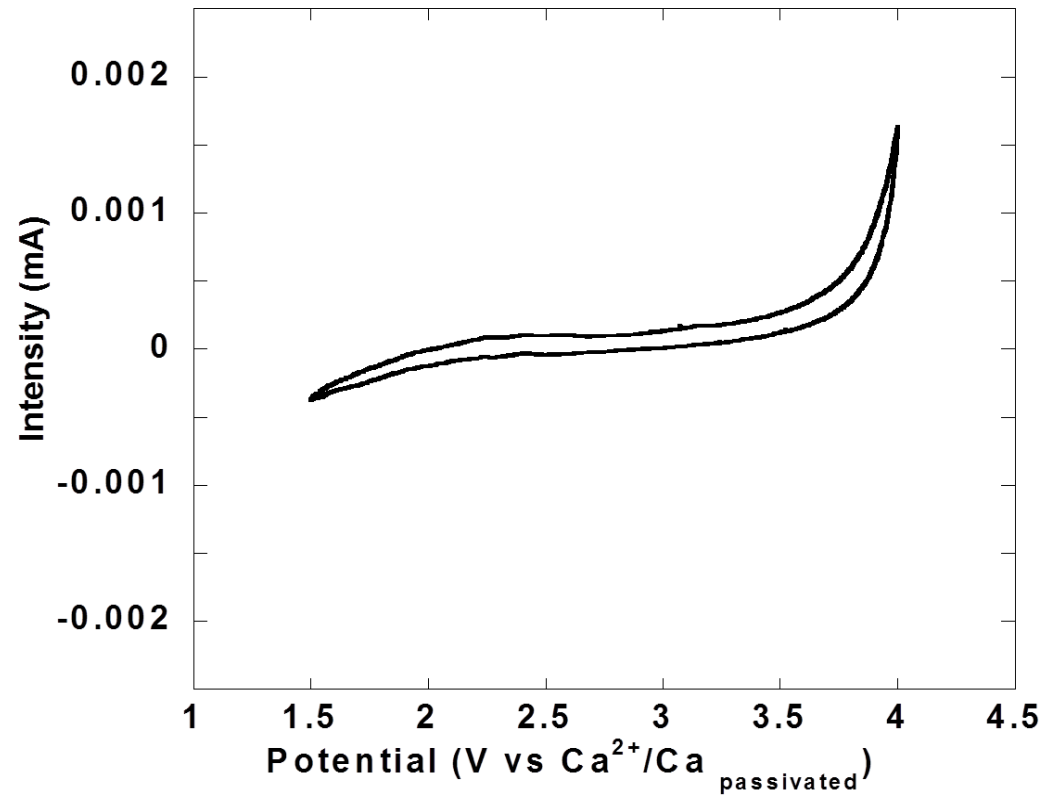

Figure S5. Cyclic voltammogram $(0.2 \mathrm{mV} / \mathrm{s})$ for $0.45 \mathrm{M} \mathrm{Ca}\left(\mathrm{BF}_{4}\right)_{2}$ in $\mathrm{EC}: \mathrm{PC}$ at $100^{\circ} \mathrm{C}$. 


\section{References}

1. Greenwood, N.N., Earnshaw, E.A. Chemistry of the Elements (Pergamon Press, 1984)

2. Electrochemical Series in CRC Handbook of Chemistry and Physics (Internet Version 2005,

David R. Lide, ed., <http://www.hbcpnetbase.com>, CRC Press, Boca Raton, FL, 2005)

3. Shannon, R.D. Effective Ionic Radii in Oxides and Fluorides. Acta Cryst. B 25, 925-946 (1969)

4. Ding, M.S. Conductivity and viscosity of PC-DEC and PC-EC solutions of LiBF4. J. Electrochem. Soc. 151, A40-A47 (2004)

5. Bjerrum, N. K. Dan. Vidensk. Selsk. Mat-fys. Medd. 7, 9 (1926)

6. McLin, M.G., Angell, C.A. Ion-Pairing Effects on Viscosity/Conductance Relations in Raman-Characterized Polymer Electrolytes: LiClO4 and NaCF3S03 in PPG (4000). J. Phys. Chem. 95, 9464-9469 (1991) 